\title{
Solutions for retrofitting existing, wooden houses in cold climates
}

\author{
Bozena Dorota Hrynyszyn ${ }^{1, *}$ and Zhiyong $\operatorname{Tian}^{1}$ \\ ${ }^{1}$ Norwegian University of Science and Technology, Department of Civil and Environmental Engineering, Trondheim, Norway
}

\begin{abstract}
Upgrading existing one-family houses to higher energy standards can be a challenge for owners, among others, due to the unclear status of technical regulations in the case of retrofitting at the national level. Retrofitting projects face technical obstacles that can be difficult to exclude with sensible measures. As a result, retrofitting projects are more difficult to complete. How can we effectively increase the rate of retrofitting projects for private owned residential buildings? Challenges associated with a complete renovation were listed, analysed and illustrated based on one of the smallest Norwegian typical wooden houses from the 1960s. Optimal packages of solutions for the retrofitting, based on energy simulation models, were proposed. The analysis showed that existing buildings are vulnerable meeting today's, much stronger, energy requirements equal for all buildings. More attention should be given to the development of separate regulations at the national level as well as to the development of retrofitting solutions, if the goal of increasing the number of renovations is to be achieved. The efficient use of solar energy becomes an important measure, especially in the context of expected climate change, and a key to achieve sustainable energy management and a better indoor climate. To avoid unnecessary cooling loads and ensure optimal thermal comfort for residents, overheating criteria should be included in energy requirements even in cold climates in the near future.
\end{abstract}

\section{Introduction}

The rate of building renovation needs to be increased, as the existing building stock represents the single biggest potential sector for energy savings. Moreover, buildings are crucial to achieving the Union objective of reducing greenhouse gas emissions by $80-95 \%$ by 2050 compared to 1990 according to the Directive 2012/27/EU of the European Parliament and of the Council of the European Union [1].

$70-80 \%$ of the buildings that will be used in 2050 are built. Use and reuse of the elderly building components and materials instead of demolition and construction new ones is considered as an important environmental protection [2].

However, upgrading existing buildings to higher energy standards can often be technically more difficult than building new ones. Retrofitting projects are more difficult to plan because they are often associated with a high degree of uncertainty. The most important restrictions apply to the determined location and geometry of existing buildings, as well as the general condition of the existing structure and the durability of components and materials to be reused. The initial phase of the planning process in the event of a complete renovation needs to be expanded by the necessary investigation and probably replacement of damaged items, which can lead to a significant increase in investment costs and ultimately be considered ineffective from the developer's point of view. Therefore, deliberate demolition with reuse of some components and materials can in some cases be considered more sustainable when it comes to environmental protection. Thus, each renovation project should be planned individually.

Another important limitation is associated with increasing awareness and ambitions in terms of carbon neutral and energy efficient buildings, neighbourhood and society without compromising quality of life. The minimum technical requirements for buildings are becoming stricter at both on international and national levels, and new restrictive regulations must be consistently implemented also in the case of renovation projects. This can be seen as a significant limitation by developers considering retrofitting as an option. How can we effectively increase the rate of retrofitting projects for private owned residential buildings?

Challenges associated with a complete renovation were mentioned, analysed and illustrated based on the characteristic building structure that have been used to build various types of wooden residential houses in Norway [3] as shown in Figure 3. Optimal packages of solutions were proposed for the renovation of the Norwegian typical wooden house form the 1960s, including mechanical components, based on energy simulation models in the context of current energy requirements the existing buildings should be met after complete renovation in Norway today. The analysis showed that existing buildings, especially the older and

\footnotetext{
* Corresponding author: bozena.d.hrynyszyn@ntnu.no
} 
smallest, were vulnerable facing new, much stronger energy requirements equal for all buildings. Due to the lack of separate technical regulations for existing buildings at the national level, the international EnerPHit Standard proposed by the Passive House Institut in Darmstadt (PHI) was used for the analysis to find out how the existing building perform after adjusting the minimum energy requirements, as little study on this topic was found.

Packages of solutions based on energy requirements adapted to existing buildings, the international EnerPHit Standard, were compared with packages of solutions capable of meeting the Norwegian minimum energy requirements in the Norwegian Building Act of 2010, (Pbl2010/TEK17). It was found that EnerPHit criteria are likely to be more often used in practice for existing buildings and recommended.

The differences between the standards compared in the analysis can be found in Table 2, Table 3 and Table 4. EnerPHit criteria, including the allowable overheating limit, force designers to pay more attention to the balance between transparent and non-transparent components of building envelope as one of the key design tools to avoid unnecessary cooling loads and provide optimal thermal comfort for residents using primarily passive cooling strategies and resources available in cold climates. EnerPHit criteria have been found to enforce more efficient management of available passive solar energy, including energy gains and losses associated with the use of transparent building envelope components in design strategies, and forcing buildings to produce renewable energy to meet their own needs.

\section{Case: retrofitting of the Norwegian typical wooden house from the 1960 s}

The modernization object is one of the smallest and easiest Norwegian typical wooden houses from the 1960s, as shown in Fig. 1, with a simple economic onestory plan, useless space in the attic and without a basement. Its architectural form cannot be considered compact and optimal in terms of energy efficiency and therefore one of the most challenging to be upgraded.

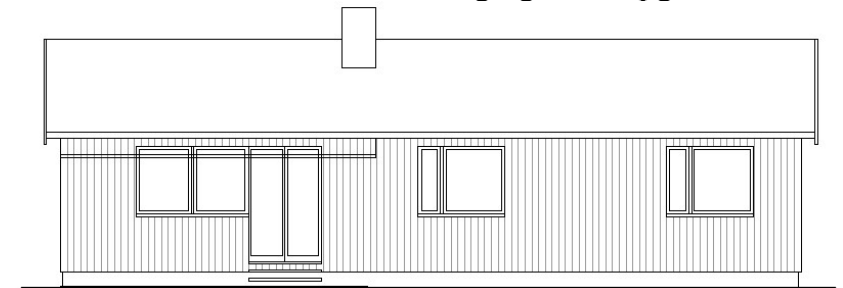

SOUTH

Fig. 1. Existing house; $90 \mathrm{~m}^{2}$, WWR 0.15 .

On the contrary, its location can be considered preferable with longer façade facing south. The treatment area (BRA), $90 \mathrm{~m}^{2}$ before renovation, was increased to $120 \mathrm{~m}^{2}$ and the window-to-wall ratio (WWR) was increased from 0.15 to 0.25 as shown in Fig. 1 and Fig. 2.

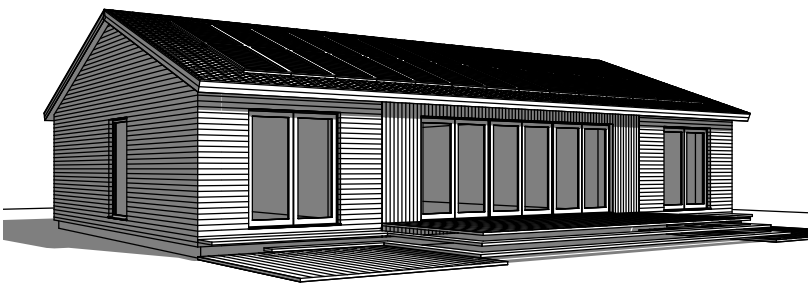

Fig. 2. Retrofitted, extended house; $120 \mathrm{~m}^{2}$, WWR 0.25 .

\subsection{Construction}

The selected house was built in the traditional Norwegian wooden framework construction, with a suspended floor above a ventilated crawling space and a ventilated cold attic as shown below in Fig. 3.

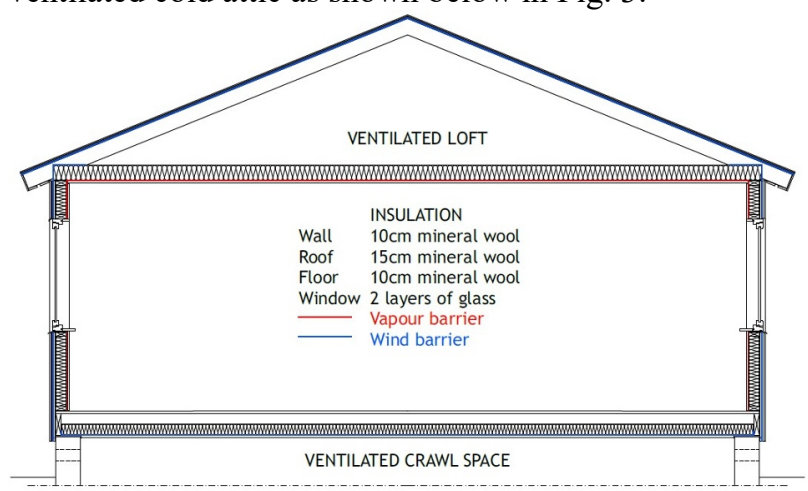

Fig. 3. Construction of the existing house from the 1960s.

Already in the 1970s, in accordance with the amendment to the Norwegian Building Act of 1969, more energy-efficient options of the construction were introduced and they were usually used, with respectively 15 or $20 \mathrm{~cm}$ insulation in external walls, 20 or $25 \mathrm{~cm}$ insulation in the roof and $20 \mathrm{~cm}$ insulation in the floor in both variants. The latter was considered the most economically optimal at that time [3]. It should be mentioned that residential buildings built since the amendment in Norway, i.e. from the 1970s, were usually larger and more compact, often built as two- or threestory houses with a basement and much more energy efficient even in the light of current minimum energy requirements (Pbl2010/TEK17). Therefore, their further improvement in energy efficiency can be achieved without additional insulation of building envelope components today, using alternative and more efficient mechanical components as well as more efficient energy management using building automation [4-5].

\subsection{Regulations}

The analysed house was built in accordance with the Norwegian Building Act of 1949 [6]. Characteristic values of the heat transfer coefficient (U-values) for building envelope components as shown in Table 1. 
Table 1. Characteristic U-values.

\begin{tabular}{|c|c|c|c|}
\hline Component & $\begin{array}{c}\text { External } \\
\text { wall }\end{array}$ & Roof & Floor \\
\hline U-value $^{1}$ & $\begin{array}{c}0.4 \\
{\left[\mathrm{~W} /\left(\mathrm{m}^{2} \mathrm{~K}\right)\right]}\end{array}$ & $\begin{array}{c}0.25 \\
{\left[\mathrm{~W} /\left(\mathrm{m}^{2} \mathrm{~K}\right)\right]}\end{array}$ & $\begin{array}{c}0.39 \\
{\left[\mathrm{~W} /\left(\mathrm{m}^{2} \mathrm{~K}\right)\right]}\end{array}$ \\
\hline $\begin{array}{c}\text { Insulation } \\
\text { thickness }\end{array}$ & $\begin{array}{c}10 \\
{[\mathrm{~cm}]}\end{array}$ & $\begin{array}{c}15 \\
{[\mathrm{~cm}]}\end{array}$ & $\begin{array}{c}10 \\
{[\mathrm{~cm}]}\end{array}$ \\
\hline
\end{tabular}

Footnotes: ${ }^{1}$ Calculated values; Estimated U-value for windows and doors (double glass): $2.8 \mathrm{~W} /\left(\mathrm{m}^{2} \mathrm{~K}\right)$

Four retrofitting scenarios were proposed and analysed:

1) to achieve the minimum Norwegian energy requirements for residential buildings, Pbl2010/TEK17,

2) to achieve the alternative Norwegian low energy criteria for residential buildings, Pbl2010/TEK17 Plus,

3) to achieve the international EnerPHit Classic criteria, (PHI),

4) to achieve the international EnerPHit Plus criteria, (PHI).

Criteria for meeting the proposed energy levels are shown in Table 2 and Table 3. Minimum energy requirements (Pbl2010/TEK17) apply to all buildings and should be implemented in the case of complete renovation of existing buildings if no exemption is sought and granted. In the case of residential buildings, another method can be used for documentation of achieving alternative low energy requirements (Pbl2010/TEK17 Plus) [7]. Norwegian Standard NS 3700:2013 [8] contains criteria for passive house and low-energy buildings for residential buildings. Since these criteria also apply to all buildings and do not take into account the specific situation of existing buildings, the international EnerPHit Standard proposed for retrofitting projects in different climate zones by the Passive House Institut in Darmstadt (PHI) in 2015 [9] was compared with the Norwegian energy requirements. The international EnerPHit Standard proposes two different methods for achieving the retrofitting criteria:

1) EnerPHit criteria for retrofitting with passive house components for retrofitting objects that meet obstacles to an energy efficient upgrade,

2) EnerPHit criteria for retrofitting with the energy demand method for retrofitting objects with more favourable pre-conditions.

The analysed type of house is expected to meet the latter criteria shown in Table 2 [10].
Table 2. EnerPHit criteria according to the energy demand method (cold climate zone, in accordance with the PHI).

\begin{tabular}{|c|c|c|}
\hline $\begin{array}{c}\text { Climate zone } \\
\text { (PHPP) }\end{array}$ & $\begin{array}{c}\text { Max. heating } \\
\text { demand } \\
\text { (HD) }\end{array}$ & $\begin{array}{c}\text { Max. cooling }+ \\
\text { dehumidification } \\
\text { demand }\end{array}$ \\
\hline Cold & $\begin{array}{c}30 \\
{\left[\mathrm{kWh} /\left(\mathrm{m}^{2} \mathrm{a}\right)\right]}\end{array}$ & $\begin{array}{c}\text { Equal to } \\
\text { Passive House } \\
\text { requirement }\end{array}$ \\
\hline
\end{tabular}

More detailed criteria, including requirements for renewable primary energy demand (PER) and requirements for renewable energy generation (REG), can be found in the EnerPHit Standard [11].

Table 3. Energy efficiency criteria for building envelope components in accordance with the Pbl2010/TEK17.

\begin{tabular}{|c|c|c|}
\hline Criteria & $\begin{array}{c}\text { Pbl2010 } \\
\text { TEK17 }\end{array}$ & $\begin{array}{l}\text { Pbl2010 } \\
\text { TEK17 Plus }\end{array}$ \\
\hline $\begin{array}{l}\text { U-value } \\
\text { Wall }\end{array}$ & $\begin{array}{c}\leq 0.22 \\
{\left[\mathrm{~W} /\left(\mathrm{m}^{2} \mathrm{~K}\right)\right]}\end{array}$ & $\begin{array}{c}\leq 0.18 \\
{\left[\mathrm{~W} /\left(\mathrm{m}^{2} \mathrm{~K}\right)\right]}\end{array}$ \\
\hline $\begin{array}{l}\text { U-value } \\
\text { Roof }\end{array}$ & $\begin{array}{c}\leq 0.18 \\
{\left[\mathrm{~W} /\left(\mathrm{m}^{2} \mathrm{~K}\right)\right]}\end{array}$ & $\begin{array}{c}\leq 0.13 \\
{\left[\mathrm{~W} /\left(\mathrm{m}^{2} \mathrm{~K}\right)\right]}\end{array}$ \\
\hline $\begin{array}{l}\text { U-value } \\
\text { Floor }\end{array}$ & $\begin{array}{c}\leq 0.18 \\
{\left[\mathrm{~W} /\left(\mathrm{m}^{2} \mathrm{~K}\right)\right]}\end{array}$ & $\begin{array}{c}\leq 0.10 \\
{\left[\mathrm{~W} /\left(\mathrm{m}^{2} \mathrm{~K}\right)\right]}\end{array}$ \\
\hline U-value/Window/Door & $\begin{array}{c}\leq 1.20 \\
{\left[\mathrm{~W} /\left(\mathrm{m}^{2} \mathrm{~K}\right)\right]}\end{array}$ & $\begin{array}{c}\leq 0.80 \\
{\left[\mathrm{~W} /\left(\mathrm{m}^{2} \mathrm{~K}\right)\right]}\end{array}$ \\
\hline $\begin{array}{l}\text { Part of windows and } \\
\text { doors area of BRA }{ }^{1}\end{array}$ & Not specified & $\leq 25 \%$ \\
\hline Airtightness $^{2}$ & $\leq 1.51 / \mathrm{h}$ & $\leq 0.61 / \mathrm{h}$ \\
\hline$\Psi$ '’-value ${ }^{3}$ & Not specified & $\begin{array}{c}\leq 0.05 \\
{\left[\mathrm{~W} /\left(\mathrm{m}^{2} \mathrm{~K}\right)\right]}\end{array}$ \\
\hline $\begin{array}{l}\text { Primary energy demand } \\
\qquad(\mathrm{PE})\end{array}$ & $\begin{array}{c}100+1600 / \mathrm{m}^{2} \\
\mathrm{BRA}^{1} \\
{\left[\mathrm{kWh} /\left(\mathrm{m}^{2} \mathrm{a}\right)\right]}\end{array}$ & $\begin{array}{l}\text { Alternative } \\
\text { criteria }^{4}\end{array}$ \\
\hline
\end{tabular}

Footnotes: ${ }^{1}$ Treatment, heated, area; ${ }^{2}$ Air leakage rate per hour at $50 \mathrm{~Pa}$ pressure difference; ${ }^{3}$ Normalized cold-bridge coefficient; ${ }^{4}$ Energy measures (Pb12010/TEK17 Plus) which can be waived provided that the building's heat loss coefficient do not increase, while at the same time the minimum energy requirements (Pb12010/TEK17) are not exceeded; Criteria for mechanical components specified for Pbl2010/TEK17 Plus: Heat recovery coefficient $(\mathrm{HR}) \leq 80 \%$, while specific fan effect in a ventilation system $(\mathrm{SFP}) \leq 1,5\left[\mathrm{~kW} /\left(\mathrm{m}^{3} / \mathrm{s}\right)\right]$ 


\subsection{Method}

Geometry of the retrofitted building was created in SketchUp. Energy simulation models for four proposed scenarios were analysed using the Passive House Planning Package (PHPP) [12], developed by the PHI. Even if the PHPP is matched to all the energy standards proposed by the PHI it can be successfully used as a simulation software in general. Two main retrofitting options were evaluated: an option of the house "as it is", i.e. not extended with a treatment area (BRA) of $90 \mathrm{~m}^{2}$ and an option of the house called "extended" with a treatment area of $120 \mathrm{~m}^{2}$. The window-to-wall ratio (WWR) was extended from $0.15\left(90 \mathrm{~m}^{2}\right)$ to $0.25\left(120 \mathrm{~m}^{2}\right)$.

Technical conditions for implementing the calculated results in building details were taken into account. Optimal packages of solutions for retrofitting of the analysed house were proposed, including mechanical components. Finally, challenges which retrofitting projects can meet were identified and discussed.

\section{Results}

The results of the analysis were divided in two parts, focusing first on solutions for the modernization of the building envelope components, and then on mechanical components that should be implemented to complete the recommended optimal retrofitting packages. Some of the detailed solutions that can be implemented were shown in the following illustrations, Fig.4 and Fig.5. Location of the house in different climate zones in Norway according to climate dates included in the PHPP was analyzed while only the results for the Oslo climate, found on average in relation to Bergen and Trondheim, were chosen to be presented in this article.

\subsection{Building envelope components}

The analysis confirmed that small and non-compact buildings may require larger investments to meet higher energy requirements as shown in Table 4.

The results showed that upgrading the analyzed house to today's energy requirements without expanding its treatment area and increasing the WWR was possible, but challenging. The international EnerPHit Standard appears to be easier to meet. The results showed that the component requirements could be met more easily and with relatively reasonable measures (Pbl2010/TEK17) while the other energy requirements forced that additional insulation must be oversized and therefore not recommended, marked red in the Table 4. Thus, a further retrofitting option, called Existing Plus, was analyzed to find out how the building performs if additional insulation of the non-transparent building envelope components was removed.

This type of retrofitting is preferred by owners who want to avoid the challenging complete renovation. With additional measures such as: 3 -glass windows (U-value $\left.\leq 0,8\left[\mathrm{~W} /\left(\mathrm{m}^{2} \mathrm{~K}\right)\right]\right)$ with integrated dynamic solar shading, balanced ventilation with heat recovery of at least $80 \%$, heat pump and photovoltaic system, the primary energy demand (PE) can be reduced from 577 to 253 $\left[\mathrm{kWh} /\left(\mathrm{m}^{2} \mathrm{a}\right)\right]$. The example showed that this reduced retrofitting scenario analysed was far from enough to achieve a significant reduction in the primary energy demand (PE) needed to meet today's minimum energy requirements (Pbl2010/TEK17), valid in case of a complete renovation.

The frequency of overheating is not a significant problem for the current weather conditions if the window-to-wall ratio (WWR) is at a level of 0.15 , i.e. the area of windows takes a maximum of $15 \%$ of the total external walls area. It was found that the optimal WWR for this type of houses was at a level of 0.25 while the WWR at a level of 0.40 can lead to an undesirable increase in the frequency of overheating, today and in the future, resulting in a growth of hours of unacceptable temperatures inside the house as well as a subsequent increase in the energy demand for cooling.

Table 4. Retrofitting options for the house "as it is"; $90 \mathrm{~m}^{2} / \mathrm{WWR}^{1}$ 0,15; Oslo climate (PHPP)

\begin{tabular}{|c|c|c|c|c|}
\hline $\begin{array}{l}\text { Retrofitting } \\
\text { scenario }\end{array}$ & Existing & $\begin{array}{c}\text { Pbl2010 } \\
\text { TEK17 }\end{array}$ & $\begin{array}{c}\text { Pbl2010 } \\
\text { TEK17 } \\
\text { Plus }\end{array}$ & $\begin{array}{l}\text { EnerPHit } \\
\text { Classic } \\
\text { and Plus }\end{array}$ \\
\hline $\begin{array}{l}\text { Insulation } \\
\text { Wall }\end{array}$ & $\begin{array}{c}10 \\
{[\mathrm{~cm}]}\end{array}$ & $\begin{array}{c}20 / 45(!) \\
{[\mathrm{cm}]}\end{array}$ & $\begin{array}{c}25 \\
{[\mathrm{~cm}]}\end{array}$ & $\begin{array}{c}25 / 40(!) \\
{[\mathrm{cm}]}\end{array}$ \\
\hline $\begin{array}{l}\text { Insulation } \\
\text { Roof }\end{array}$ & $\begin{array}{c}15 \\
{[\mathrm{~cm}]}\end{array}$ & $\begin{array}{c}20 / 60(!) \\
{[\mathrm{cm}]}\end{array}$ & $\begin{array}{c}30 \\
{[\mathrm{~cm}]}\end{array}$ & $\begin{array}{c}30 / 55(!) \\
{[\mathrm{cm}]}\end{array}$ \\
\hline $\begin{array}{l}\text { Insulation } \\
\text { Floor }\end{array}$ & $\begin{array}{c}10 \\
{[\mathrm{~cm}]}\end{array}$ & $\begin{array}{c}25 / 40(!) \\
{[\mathrm{cm}]}\end{array}$ & $\begin{array}{c}35 \\
{[\mathrm{~cm}]}\end{array}$ & $\begin{array}{l}25 / 30 \\
{[\mathrm{~cm}]}\end{array}$ \\
\hline $\begin{array}{l}\text { Frequency of } \\
\text { overheating } \\
\text { Criteria }\end{array}$ & $\begin{array}{c}2 \% / 5 \%{ }^{7} \\
-\end{array}$ & $\begin{array}{c}2 \% / 4 \% 0^{7} \\
3 \% / 6 \% 0^{7} \\
-\end{array}$ & $\begin{array}{c}3 \% / 5 \%^{7} \\
\text { Alternative }\end{array}$ & $\begin{array}{l}3 \% / 5 \%^{7} \\
3 \% / 5 \%^{7} \\
\leq \mathbf{1 0} \%\end{array}$ \\
\hline $\begin{array}{c}\mathrm{HD}^{3} \\
\text { Criteria }\end{array}$ & 186 & $\begin{array}{l}59 \\
-\end{array}$ & $\begin{array}{c}42 \\
\text { Alternative }\end{array}$ & $\begin{array}{l}45 / 30 \\
\leq \mathbf{3 0}\end{array}$ \\
\hline $\begin{array}{c}\mathrm{PE}^{4} \\
\text { PE Criteria } \\
\text { PER }^{5} \\
\text { PER Criteria } \\
\text { REG }^{6} \\
\text { REG Criteria }\end{array}$ & $\begin{array}{c}- \\
- \\
382 \\
-\end{array}$ & $\begin{array}{c}177 / 118 \\
\leq \mathbf{1 1 9} \\
- \\
- \\
382 \\
-\end{array}$ & $\begin{array}{c}146 \\
\text { Alternative } \\
- \\
- \\
382 \\
-\end{array}$ & $\begin{array}{c}152 / 127 \\
- \\
90 / 75 \\
\leq \mathbf{9 0} / \mathbf{7 5} \\
382 \\
\geq \mathbf{7 3 / 7 3}\end{array}$ \\
\hline
\end{tabular}

Footnotes: ${ }^{1}$ Window-to-wall ratio; ${ }^{2} \mathrm{PHI}$ criteria; ${ }^{3}$ Heating Demand $\left[\mathrm{kWh} /\left(\mathrm{m}^{2} \mathrm{a}\right)\right]$; ${ }^{4}$ Primary Energy demand (Pbl2010/TEK17) $\left[\mathrm{kWh} /\left(\mathrm{m}^{2} \mathrm{a}\right)\right]$; ${ }^{5}$ Renewable Primary Energy

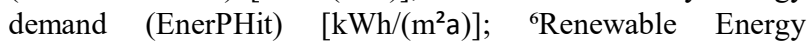
Generation (EnerPHit) $\left[\mathrm{kWh} /\left(\mathrm{m}^{2} \mathrm{a}\right)\right]$; ${ }^{7}$ Respectively: with/without summer sun protection (EnerPHit)

The recommended retrofitting scenarios for the extended option of the house with the increased windowto-wall ratio, WWR 0.25 , were shown in Table 5. 
The results showed that the extended option of the retrofitted house, $120 \mathrm{~m}^{2}$ with the higher WWR at a level of 0.25 , could meet both the components and the other energy requirements with a lower amount of additional insulation, with one exception in the Pbl2010/TEK17 Plus-option, when to meet the maximum U-value requirement for floor up to $25 \mathrm{~cm}$ insulation must be added. It can be challenging technically and not more effective compared to the other two options evaluated.

The component requirements in the Pbl2010/TEK17 can be met more easily and with reasonable measures in this case. Raising WWR to a level of 0.25 was found to be beneficial when it comes to optimal use of the passive solar energy. However, a further increase in WWR to a level of 0.40 may lead to a negative increase in the frequency of overheating and was not recommended. Finally, it is important to note that the EnerPHit criteria could be met with the most reasonable measures, while the final effect (in the form of reduced $\mathrm{HD}$ and $\mathrm{PE}$ demand) is similar for all proposed scenarios. Then the EnerPHit-option was recognized as optimal, most likely to be used in practice, and the most recommended.

Table 5. Recommended retrofitting options for the house "extended"; $120 \mathrm{~m}^{2} / \mathrm{WWR}^{1}$ 0.25; Oslo climate (PHPP)

\begin{tabular}{|c|c|c|c|c|}
\hline $\begin{array}{l}\text { Retrofitting } \\
\text { scenario }\end{array}$ & Existing & $\begin{array}{c}\text { Pbl2010 } \\
\text { TEK17 }\end{array}$ & $\begin{array}{c}\text { Pbl2010 } \\
\text { TEK17 } \\
\text { Plus }\end{array}$ & $\begin{array}{c}\text { EnerPHit } \\
\text { Classic } \\
\text { and Plus }\end{array}$ \\
\hline $\begin{array}{l}\text { Insulation } \\
\text { Wall }\end{array}$ & $\begin{array}{c}10 \\
{[\mathrm{~cm}]}\end{array}$ & $\begin{array}{l}20 / 35 \\
{[\mathrm{~cm}]}\end{array}$ & $\begin{array}{c}25 \\
{[\mathrm{~cm}]}\end{array}$ & $\begin{array}{c}25 \text { or } 30 \\
{[\mathrm{~cm}]}\end{array}$ \\
\hline $\begin{array}{l}\text { Insulation } \\
\text { Roof }\end{array}$ & $\begin{array}{c}15 \\
{[\mathrm{~cm}]}\end{array}$ & $\begin{array}{c}20 / 45(!) \\
{[\mathrm{cm}]}\end{array}$ & $\begin{array}{c}30 \\
{[\mathrm{~cm}]}\end{array}$ & $\begin{array}{c}35 \text { or } 30 \\
{[\mathrm{~cm}]}\end{array}$ \\
\hline $\begin{array}{l}\text { Insulation } \\
\text { Floor }\end{array}$ & $\begin{array}{c}10 \\
{[\mathrm{~cm}]}\end{array}$ & $\begin{array}{l}25 / 25 \\
{[\mathrm{~cm}]}\end{array}$ & $\begin{array}{c}35 \\
{[\mathrm{~cm}]}\end{array}$ & $\begin{array}{c}25 \text { or } 30 \\
{[\mathrm{~cm}]}\end{array}$ \\
\hline $\begin{array}{l}\text { Frequency of } \\
\text { overheating }\end{array}$ & $2 \% / 5 \%{ }^{7}$ & $\begin{array}{c}7 \% / 13 \%^{7} \\
7 \% / 14 \%{ }^{7} \\
-\end{array}$ & $8 \% / 14 \%^{7}$ & $\begin{array}{l}7 \% / 14 \%{ }^{7} \\
<\mathbf{1 0 \%}\end{array}$ \\
\hline $\begin{array}{c}\mathrm{HD}^{3} \\
\text { Criteria }\end{array}$ & 186 & $\begin{array}{c}43 / 28 \\
-\end{array}$ & $\begin{array}{c}30 \\
\text { Alternative }\end{array}$ & $\begin{array}{c}30 \\
\leq \mathbf{3 0}\end{array}$ \\
\hline $\begin{array}{c}\mathrm{PE}^{4} \\
\text { PE Criteria } \\
\text { PER }^{5} \\
\text { PER Criteria } \\
\text { REG }^{6} \\
\text { REG Criteria }\end{array}$ & $\begin{array}{c}- \\
- \\
306 \\
-\end{array}$ & $\begin{array}{c}139 / 112 \\
\leq \mathbf{1 1 3} \\
- \\
- \\
306 \\
-\end{array}$ & $\begin{array}{c}115 \\
\text { Alternative } \\
- \\
- \\
306 \\
-\end{array}$ & $\begin{array}{c}115 \\
- \\
66 \\
\leq 66 \\
306 \\
\geq \mathbf{6 0}\end{array}$ \\
\hline
\end{tabular}

Footnotes: ${ }^{1}$ Window-to-wall ratio; ${ }^{2} \mathrm{PHI}$ criteria; ${ }^{3}$ Heating Demand $\left[\mathrm{kWh} /\left(\mathrm{m}^{2} \mathrm{a}\right)\right]$; ${ }^{4}$ Primary Energy demand (Pbl2010/TEK17) $\left[\mathrm{kWh} /\left(\mathrm{m}^{2} \mathrm{a}\right)\right]$; ${ }^{5}$ Renewable Primary Energy demand (EnerPHit) $\left[\mathrm{kWh} /\left(\mathrm{m}^{2} \mathrm{a}\right)\right]$; ${ }^{6}$ Renewable Energy Generation (EnerPHit) [kWh/( $\left.\left.\mathrm{m}^{2} \mathrm{a}\right)\right]$; ${ }^{7}$ Respectively: with/ without summer sun protection (EnerPHit)
In Fig. 4 and Fig. 5, two different solutions found to be recommended for retrofitting the analysed house were illustrated. Calculated values of heat transfer coefficient (U-values) for the external walls as well as the roof and the floor, $\leq 0,15 \mathrm{~W} /\left(\mathrm{m}^{2} \mathrm{~K}\right)$ in line with the PHI recommendation.

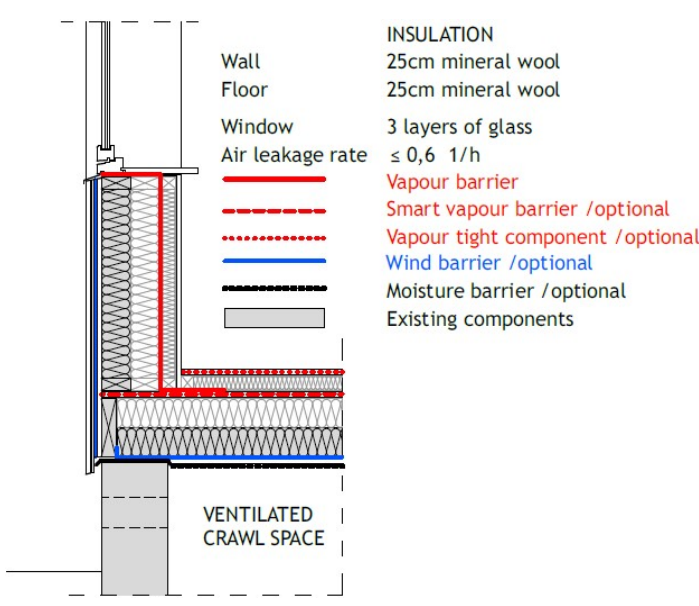

Fig. 4. Retrofitted house; EnerPHit, option A; Insulation of the external wall can be completed with $5 \mathrm{~cm}$ outside, as in Fig. 5.

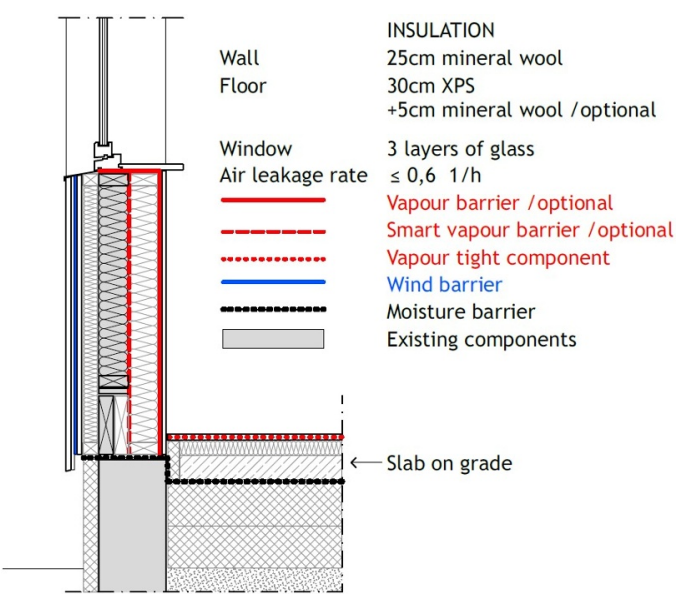

Fig. 5. Retrofitted house; EnerPHit, option B; Insulation of the external wall can be completed with $5 \mathrm{~cm}$ inside, as in Fig. 4.

\subsubsection{Improving insulation of the external walls}

Additional insulation can be added inside, outside or on both sides of the existing external walls. However, it can be a challenge, especially if the retrofitted house is small, as the house in question. Additional insulation larger than $10 / 15 \mathrm{~cm}$ inside is technically possible, but it will significantly reduce the treatment area. Therefore, it may be beneficial to add a part of the additional insulation to the outside as shown in Fig. 5. However, better insulated, thicker, and tighter external walls can face challenges due to moisture transfer when they are exposed to condensation within the structure for a long time. This risk can probably be reduced by replacing the traditional vapor-proof barrier with other products, socalled smart vapour barriers, which are now used more frequently in Central Europe. In Norway, they are not yet recommended when it comes to ventilated external 
wooden walls, but smart vapour barriers have been the subject of ongoing research in recent years [13-14]. They were tested in some pilot projects to be used as an alternative product, until now in warm compact roof constructions.

\subsubsection{Improving insulation of the roof}

The existing insulation is not expected to be in good enough condition after being over 60 years in an open and ventilated attic. Thus, the entire existing insulation should be replaced with a new one. This measure was seen as the least challenging since the new insulation can be placed in the same location, directly over the roof construction or partially below, using, for example, a blown insulation. However, whether it is desirable to move the existing insulation and place it in the rafter space, the insulation thickness should be more carefully sized.

\subsubsection{Improving insulation of the floor}

The suspended floor over a ventilated crawl space was considered challenging because of the construction's exposition on moisture-related damage when not properly ventilated or preserved. Thus, the foundation method was preferably converted to slab on grade, more and more frequently from the 1970 s, even in the case of the smallest houses on one floor.

Conversion of ventilated crawl space to slab on grade in the case of existing buildings was described and considered as a feasible measure to be implemented to improve this type of construction in Norwegian houses [15]. However, a completely open foundation is still popular and successfully used in the case of various types of housing in Canada as a practical foundation method in cold climates [16]. Then open foundation methods may become more relevant in the future due to expected climate change when the winter seasons will be more humid or the groundwater levels locally will rise.

In Fig. 4 and Fig. 5, two different solutions were proposed, when the construction of the existing ceiling is preserved (A) and replaced by slab on grade (B). However, the latter was found to be more challenging and should be considered in each case when to use it.

\subsubsection{Improving transition details}

In addition to the requirements for the normalised coldbridge coefficient, $\Psi$ " $\leq 0,05 \mathrm{~W} /\left(\mathrm{m}^{2} \mathrm{~K}\right)$, necessary to meet in case higher then the Pb12010/TEK17 energy levels, it was important to reduce the linear cold-bridge coefficient of the important transition details, $\Psi \leq 0,01$ $\mathrm{W} /(\mathrm{mK})$ in line with the PHI recommendation, as far as possible.

\subsubsection{Airtightness}

In order to meet higher than the Pbl2010/TEK17 energy requirements the air exchange rate must be kept at a level $\leq 0,61 / \mathrm{h}$. Therefore, it was important to use appropriate products such as wind, vapor-proof and moisture barrier properly. In order to meet the criteria mentioned above it was recommended that the vaporproof barrier, including important transition details, would be continuously and accurately installed.

\subsection{Mechanical components}

Mechanical components that were recommended to be used to achieve the EnerPHit Classic and Plus criteria were shown in Table 6 [17].

Table 6. Mechanical components

\begin{tabular}{|c|c|c|}
\hline Component & Existing & $\begin{array}{c}\text { EnerPHit } \\
\text { Classic \& Plus }\end{array}$ \\
\hline Heating & Electricity & $\begin{array}{c}\text { Electricity/ } \\
\text { Heat pump }\end{array}$ \\
\hline Ventilation & $\begin{array}{c}\text { EAU } \\
\text { Window }\end{array}$ & $\begin{array}{c}\text { Balanced + HR } \\
\text { Window }\end{array}$ \\
\hline $\begin{array}{c}\text { Active solar } \\
\text { shading }\end{array}$ & No & Yes \\
\hline $\mathrm{DHW}^{2}$ & Electricity & Electricity/Solar \\
\hline $\mathrm{PV}^{6}$ & No & Yes \\
\hline
\end{tabular}

Footnotes: ${ }^{1}$ System for active solar shading included in east, south and west facing windows; ${ }^{2}$ DHW: Domestic hot water; ${ }^{3} \mathrm{PV}$ : Photovoltaic systems; ${ }^{4} \mathrm{EAU}$ : Extract air unit; ${ }^{5} \mathrm{HR}$ : Heat recovery; ${ }^{6}$ Optional

The same packages of mechanical components can be used to achieve the Pbl2010/TEK17 and Pbl2010/TEK17 Plus criteria, except for heating systems that must comply with the current minimum energy requirements in Norway, described in section 3.2.1.

\subsection{Heating}

The existing house was only heated with electricity. In order to reduce the energy demand for heating significantly other heating systems, more efficient and environmentally friendly, must be implemented. Thus, a heat pump was recommended to be used. However, with regard to the current Norwegian minimum energy requirements, chimneys must be built in small houses as a secondary energy source, in accordance with the criteria in Chapter 14; $§ 14-4$; Pbl/TEK17, unless the housing unit is constructed with a water-borne heating system or the energy demand for heating does not increase the passive house requirements in accordance with Norwegian Standard NS 3700:2013 [8]. To fulfil the EnerPHit criteria, only the use of a heat pump additionally was recommended for this retrofitting project as shown in Table 6.

\subsubsection{Ventilation}

The existing house was ventilated by an extract air unit supported by a natural open-window ventilation. In order to fulfil all the analysed options, both in accordance with the Pbl/TEK17 and the EnerPHit 
criteria, a balanced ventilation unit with a minimum of $80 \%$ heat recovery was recommended to be implemented, completed by a natural open-window ventilation as shown in Table 6.

\subsubsection{Active solar shading}

For indoor comfort, it is important to avoid unwanted overheating that can also lead to an increase in the energy demand for cooling, even in cold climates and in today's weather conditions.

PHI defines the risk of overheating of a building with a frequency when temperatures are calculated to rise above an established comfort limit $\mathrm{T}_{\max }$. The frequency is expressed as a percentage of annual indoor hours. The default $\mathrm{T}_{\max }$ used in PHPP is $25^{\circ} \mathrm{C}$. The PHI guidelines recommend that when the frequency of temperatures in excess of the comfort limit exceeds $10 \%$ of the annual occupied hours, additional measures for summer sun protection will be necessary. The guidelines also recommend that the frequency of temperatures in excess of the comfort limit should not exceed $5 \%$ of annual occupied hours to guarantee a high summer comfort.

It was found that the overheating risk in the existing house was at an appropriate level of 5\% without and $2 \%$ with a temporary summer sun protection when the WWR was at a level of 0.15 . However, to use the passive solar energy optimally, the WWR should be increased to 0.25 . For this option, extended house to $120 \mathrm{~m}^{2}$, it was found that overheating risk will grow to a level of $14 \% / 7 \%$ respectively without and with a sun protection. It is still an appropriate scenario. Further increases in WWR above a level of 0.30 were found impractical resulting in too excessive growth of overheating. Two of the analysed scenarios, WWR 0.25 and WWR 0.40 that meet the EnerPHit criteria, were shown in Fig. 7. In order to avoid unwanted overheating, it was recommended to include a dynamic solar shading system that could work temporarily and automatically according to changing conditions in the windows facing east, south and west.

Intelligent control systems integrated with windows to optimize the solar energy contribution more dynamically, to increase the well-being of residents when it comes to indoor climate conditions and at the same time improve the building's energy performance, will be needed now and in the future due to the expected climate change [18].

\subsubsection{PV and DHW}

The renewable energy generation from photovoltaics (PV) placed on the southern oriented roof deck was simulated. Domestic hot water demand (DHW) was proposed primarily covered by photovoltaics producing at least $382 \mathrm{kWh} /\left(\mathrm{m}^{2} \mathrm{a}\right)$ of renewable solar energy. When PV is not enough, backup electricity will be used.

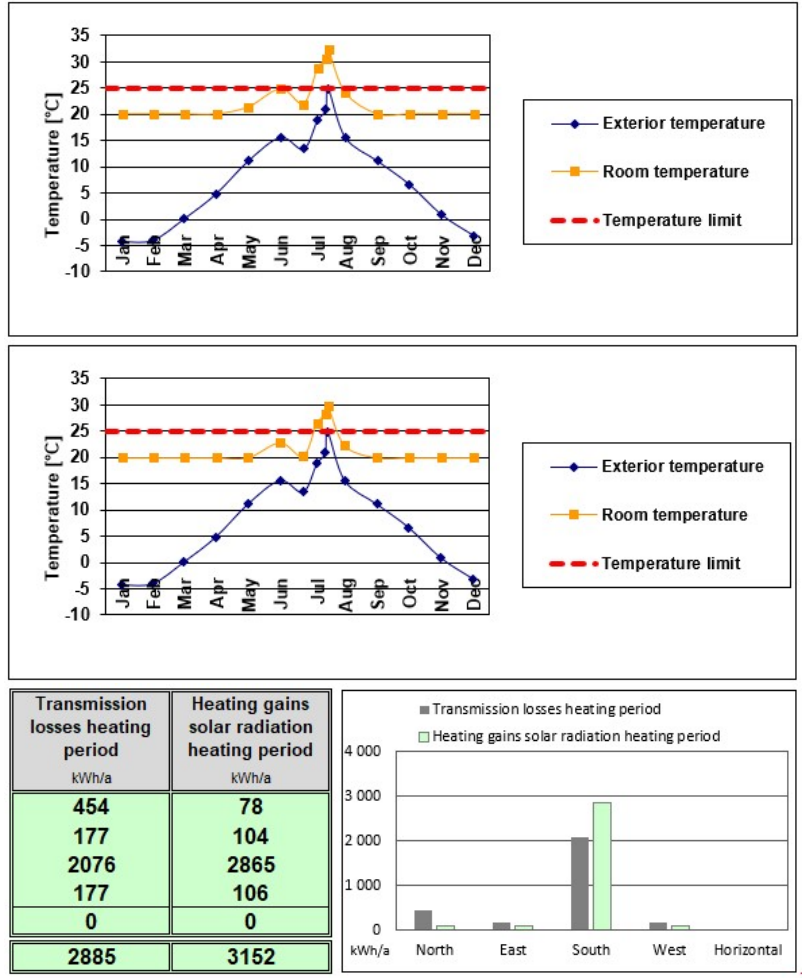

a) Retrofitted, extended house; $120 \mathrm{~m}^{2} / \mathrm{WWR} 0.25$; EnerPHit, respectively without/with a dynamic solar shading.

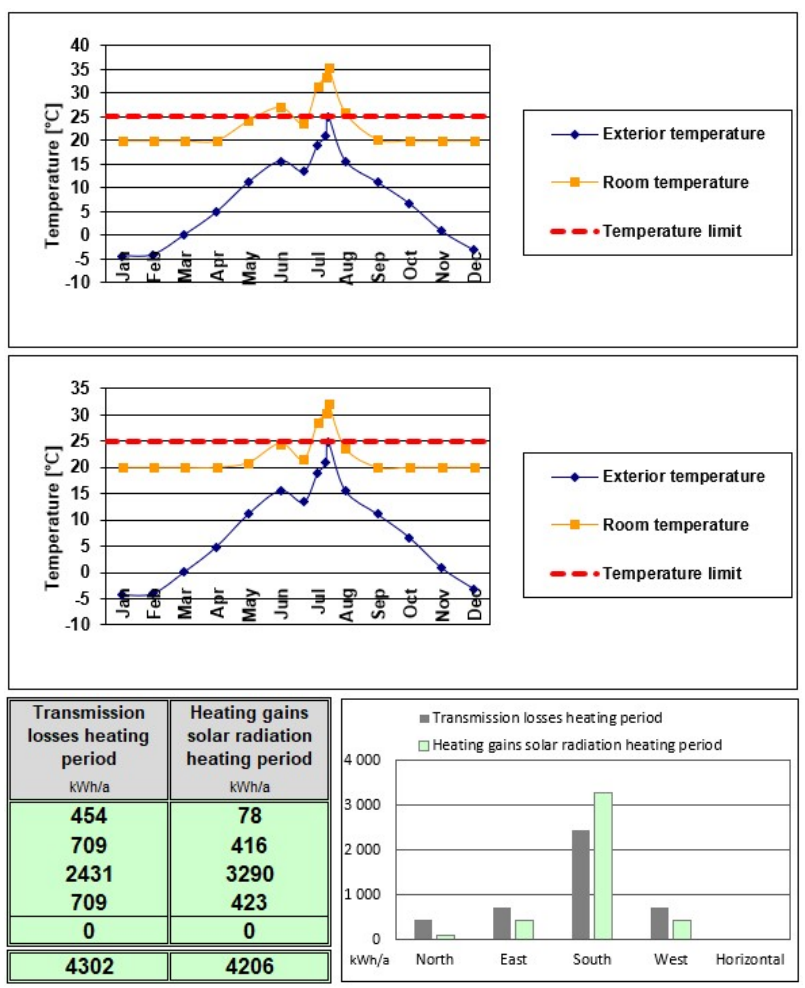

b) Retrofitted, extended house; $120 \mathrm{~m}^{2} / \mathrm{WWR} 0.40$; EnerPHit, respectively without/with a dynamic solar shading.

Fig. 7. Overheating risk vs. saving potential of solar energy.

\section{Conclusion}

Most of the buildings we use today, about $80 \%$, were built in the past. 30-60 years old buildings are often considered outdated and not enough energy efficient, 
environmentally friendly or comfortable in light of today's technical requirements being increasingly tightened. How can we effectively increase the rate of retrofitting projects for private owned residential buildings?

Upgrading existing buildings to the analysed energy standards is technically feasible, although more or less challenging. The smaller buildings the more vulnerable.

Architectural measures, such as a balanced windowto-wall ratio or extension of the treatment area, should be noted.

The results showed that the minimum energy requirements for components were easier to meet by the smallest buildings than the primary energy requirements (PE) in Pbl2010/TEK17. As a result, to meet the primary energy requirements, building envelope components may be oversized in terms of the amount of additional insulation.

Technical regulations at the national level should contain separate energy requirements for retrofitting existing buildings.

Achieving the international EnerPHit criteria, adapted to existing buildings in different climate zones, was found to be the least challenging and applicable in the analyzed case, and therefore considered optimal and recommended.

Overheating criteria have been found necessary to be included in energy requirements to ensure the optimal performance of building components in terms of energy efficiency as well as indoor climate quality.

Development of retrofitting solutions, such as preapproved building details, is necessary to increase the rate of retrofitting projects as well.

Specific building details that can be implemented in the presented retrofitting packages were further developed with students in the subject Building Technology 2 at NTNU. The authors would like to acknowledge the Norwegian University of Science and Technology (NTNU), the Faculty of Engineering and the Department of Civil and Environmental Engineering for financial support of the research.

\section{References}

1. European Parliament (Council of the European Union). Directive 2012/27/EU of the European Parliament and of the Council of the European Union, (2018)

2. Norsk Kommunalteknisk Forening, Tekniske krav ved tiltak $i$ eksisterende bygg, (NKF, 2016)

3. H. Granum et.al., Boligen og energiforbruket, Rapport STF62 A78003, 40, (SINTEF, 1978)

4. L. C. Felius, F. Dessen, B.D. Hrynyszyn, Retrofitting towards energy-efficient homes in European cold climates: a review, Energy Efficiency, (2019)

5. L. C. Felius, M. Hamdy, B. D. Hrynyszyn, F. Dessen, The impact of building automation control systems as retrofitting measures on the energy efficiency of a typical Norwegian single-family house, SBE19, Thessaloniki, Greece, (2020)

6. Direktoratet for byggkvalitet (DiBK) Homepage, Norwegian Building Act, Byggeforskrift 1949, https://dibk.no/globalassets/byggeregler/tidligere re gelverk/historisk-arkiv-1949---1987/byggeforskrift1949-bind-i.pdf, (Last accessed 01.2020)

7. Direktoratet for byggkvalitet (DiBK) Homepage, Byggteknisk forskrift (TEK17), https://dibk.no/byggereglene/byggteknisk-forskrifttek17/14/14-2/, (Last accessed 01.2020)

8. Standard Norge, NS 3700:2013 Criteria for passive houses and low energy buildings - Residential buildings, Standard Norge SN, (2013)

9. Z. Bastian, Passive House Institute Introduces New an Updated Building Certification Criteria, Passive House Institute (PHI), 7. Passivhus Norden Copenhagen, Denmark, (2015)

10. B. D. Hrynyszyn, L.C. Felius, Upgrading of a Typical Norwegian Existing Wooden House According to the EnerPHit Standard, Cold Climate HVAC 2018. Sustainable Buildings in Cold Climates, In: Editors, D. Johansson, Hans Bagge, Åsa Wahlström, Springer Nature Switzerland AG, 183, (2019)

11. PHI Homepage, Step by Step Retrofits with Passive House Components, In: Editor, Z. Bastian (2016), www.europhit.eu, (Last accessed 01.2020)

12. Passive House Institute (PHI), Passive House Planning Package (PHPP, Version 9)

13. A. Dalehaug, M. Agnalt, S. Geving, Smart vapour barriers in passive house walls - a way to make the structure more moisture robust? Proceedings of the 10th Nordic Symposium on Building Physics, Lund, Sweden, Grafisk gruppen AB 2014, 1132, (2014)

14. S. Geving, T-A. Olsen, Compact wooden roofs with smart vapour barriers - effect of wooden joists on drying of built-in moisture, 4th Central European symposium on building physics (CESBP), MATEC Web of Conferences 282, 02009, (2019)

15. S. Geving, Fuktskader. Arsaker, utredning og tiltak, SINTEF akademisk forlag, 57, (2011)

16. Ch. Harries, Review of Current Practice of Building Foundations in the Canadian North, Cold Climate HVAC 2018. Sustainable Buildings in Cold Climates, In: Editors, D. Johansson, Hans Bagge, Åsa Wahlström, Springer Nature Switzerland AG, 1055, (2019)

17. B. D. Hrynyszyn and Z. Tian, Retrofitting according to the EnerPHit Standard in cold climates - components, Conference Proceedings of the 23th International Passive House Conference, Gaobeidian, China, In: Editor, W. Feist, PHI, (2019)

18. Z. Tian and B. D. Hrynyszyn, Overheating risk of a typical Norwegian residential building retrofitted to higher energy standards, Nordic Symposium on Building Physics, NSB2020, Tallinn, Estonia, (to be published) 